\title{
Ethnobotanical study based on the five dimensions of basic life needs in Tidung Tribe of North Kalimantan, Indonesia
}

\author{
ALFI SUCIYATI ${ }^{1,3, \boldsymbol{v}}$, I GUSTI PUTU SURYADARMA ${ }^{2}$, PAIDI $^{2}$, FADHLAN MUCHLAS ABRORI $^{3}$ \\ ${ }^{1}$ Doctoral Program in Biology Education, Graduate School, Universitas Negeri Yogyakarta. J1. Colombo No. 1, Karang Malang, Sleman, 55281, \\ Yogyakarta, Indonesia. Tel.: +62-274-550836, Fax.: +62-274-520326, `email: alfisuciyati.2018@student.uny.ac.id; alphie120115@gmail.com \\ ${ }^{2}$ Department of Biology Education, Faculty of Mathematics and Natural Sciences, Universitas Negeri Yogyakarta. Jl. Colombo No. 1, Karang Malang, \\ Sleman, 55281, Yogyakarta, Indonesia \\ ${ }^{3}$ Department of Biology Education, Faculty of Teacher Training and Education, Universitas Borneo Tarakan. Jl. Amal Lama No. 1, Tarakan 77123, North \\ Kalimantan, Indonesia
}

Manuscript received: 27 November 2020. Revision accepted: 16 May 2021.

\begin{abstract}
Suciyati A, Suryadarma IGP, Paidi Abrori FM. 2021. Ethnobotanical study based on the five dimensions of basic life needs in Tidung Tribe of North Kalimantan, Indonesia. Biodiversitas 22: 3199-3208. The Tidung tribe is one of the original inhabitants of North Kalimantan, Indonesia. Research results related to the Tidung tribe, especially those related to ethnobotany, are still rare. This research aimed to make an inventory of plant species used by Tidung Tribe based on the five dimensions of basic life needs of Tidung Tribe. The five dimensions of basic life needs of Tidung Tribe is that plants are useful as food (ngakan), shelter (baloy), health/medicine (sihat), traditional ceremony (adat), and clothing (memana). Informants were obtained by conducting snowball sampling consisting of 22 family heads and as many as 65 people. There were three instruments in the data collection: questionnaires of list of plant species, quantitative plant assessment instruments, and semi-structured interviews. According to the inventory result, Tidung Tribe utilize 60 plant species in their daily life. Most of these plants are used as food (ngakan) and traditional medicine (sihat). The Availability Index and Frequency Use Index data showed that Arecaceae, Pandanaceae, Solanaceae, Zingiberaceae, and Poaceae families were the most widely available plants in the research location and most often used by the community.
\end{abstract}

Keywords: biodiversity conservation, Indonesia, local ecological knowledge, quantitative ethnobotany, Tidung Tribe

Abbreviations: AI: Availability Index, FUI: Frequency Use of Index, PUI: Part Used of Index

\section{INTRODUCTION}

Indonesia, having many ethnic groups and ecosystem types, is rich in natural and cultural resources (Suryadarma 2019). There are at least 633 ethnic groups consisting of 1331 tribes in Indonesia (Ananta et al. 2014; BPS 2012). Each tribe in Indonesia has a certain perspective on the use of natural resources, especially plants. Several cultures related to the uses of plants have been documented in some ethnobiological studies.

Ethnobiology is expected to have capability to deal with the ecological and humanitarian crises in the $21^{\text {st }}$ century. Biocultural heritage can contribute to a local innovation process that will meet community needs (Davidson-Hunt et al. 2012; Hidayati et al. 2015). The biocultural concept in ethnobiological research has been carried out by many researchers, such as Maffi (2007), Cocks (2010), Sterling et al. (2010), and Rotherham (2015).

Indonesia as a multicultural country has multibiodiversity characteristics (Simbiak et al. 2019). Every ethnic group in Indonesia has a biocultural heritage that needs to be explored to encourage the creation of a local innovation process. The plant diversity used by Tidung tribe in North Kalimantan is still rarely researched, and is still difficult to find literature on the use of plants by the Tidung Tribe. Several studies related to ethnobiology, especially ethnobotany in the Tidung tribe, have been carried out in several areas, namely: Tarakan, Sembakung, and Bulungan. Ethnobiological studies carried out were the use of herbs and spices and the use of medicinal plants for traditional ceremonies (Lesmana et al. 2018; Listiani and Abrori 2019).

There is a link between the use of natural resources and the social system as a unique cultural feature of the local community (Suryadarma 2011). Tidung Tribe has a lifestyle in which many plant species are used for food (ngakan), shelter/construction (baloy), health/medicine (sihat), traditional ceremony (adat), and clothing (memana). Tidung Tribe implements this lifestyle to optimize the use of natural sources. Therefore, they make each part of the plants as useful as possible for daily needs. People's reliance on different plant species allows them to sustain their livelihood and meet their different material and non-material needs.

Ethnobotany studies have been done in several areas where the Tidung Tribe lives, but no ethnobotany studies have been conducted in other areas where the largest Tidung Tribe communities live, one of which is Tana Tidung District. Therefore, this research was done in Tana Tidung District with the objectives of documenting: (i) the species of plants used by the Tidung tribe based on the five dimensions of their basic needs, (ii) the availability of these 
plants in nature (based on AI values), (iii) the frequency of these plant used by the Tidung tribe (based on the FUI value), (iv) the plant parts of each species used (based on the PUI value).

\section{MATERIALS AND METHODS}

\section{Study area}

Tana Tidung District is located at $3012^{\prime \prime} 02^{\prime \prime}-3046^{\prime}$ 41" N, 1160 42' 50" - 1170 49' 50" E. Tana Tidung District is one of the regencies in North Kalimantan bordering with Nunukan (on the north), Tarakan (on the east), Bulungan (on the south) and Malinau (on the west). Tana Tidung District has an area of $4,828.58 \mathrm{Km}^{2}$ and consists of five sub-districts: Sesayap, Sesayap Ilir, Betayau, Muruk Rian, and Tana Lia (Tana Tidung District Goverment 2012).

Tana Tidung District is crossed by three large rivers (Figure 1), namely Kayan River (576 Km), Bandan River $(70 \mathrm{Km})$, and Sesayap River $(278 \mathrm{Km})$ (Tana Tidung District Government 2015). Tana Tidung District is located at altitudes between $250 \mathrm{~m}$ and $2000 \mathrm{~m}$. There is a steep plateau overgrown with wilderness, hills, and mountains with altitudes of \pm 500 - $2000 \mathrm{~m}$. Tana Tidung District has several islands flowed by dozens of large rivers and small rivers. The islands have hilly terrain, with steep cliffs and sharp slopes.

\section{Data collection}

The research was conducted from December 2019 to October 2020. Data about the use of plants in the Tidung tribe consisting of the usefulness in food consumption (ngakan), shelter/construction (baloy), herbal medicine (sihat), traditional ceremonies (adat), and clothing (memana) were gathred from 65 informants from 22 families, selected using snowball sampling technique. The informants have experience in using plants based on the life philosophy of Tidung Tribe. Snowball started with data collection from traditional leaders, traditional medicine practitioners, fishermen, carpenters, farmers and local residents to serve as respondents. The snowball process was considered complete after the data obtained were saturated.

There were three instruments used in the data collection namely questionnaires of list of plant species, quantitative plant assessment instruments, and semi-structured interviews. Quantitative plant assessment was conducted to measure society's perception related to the plants in the form of numbers. The assessor refers to Pieroni's instrument (2001). Values measured were Availability Index (AI) (Table 1), Frequency Use Index (FUI) (Table 2), and Part Used Index (PUI) (Table 3). AI describes the availability of plants based on resident's perceptions. FUI describes the frequency of plant utilization per time. PUI describes various uses of various parts of similar plants.

The last data collection instrument was semi-structured interviews to record how the informants knew plants used in daily life. The main questions being asked were: (i) how do you use the plants? (ii) how often do you use the plants in your daily activities? (iii) which parts of plants are used? Interviews were conducted to: (i) get a list of plant names, and (ii) obtain information about the availability, use frequency, and parts of plants used. From these data, quantitative indexes (AI, FUI, PUI) were calculated.
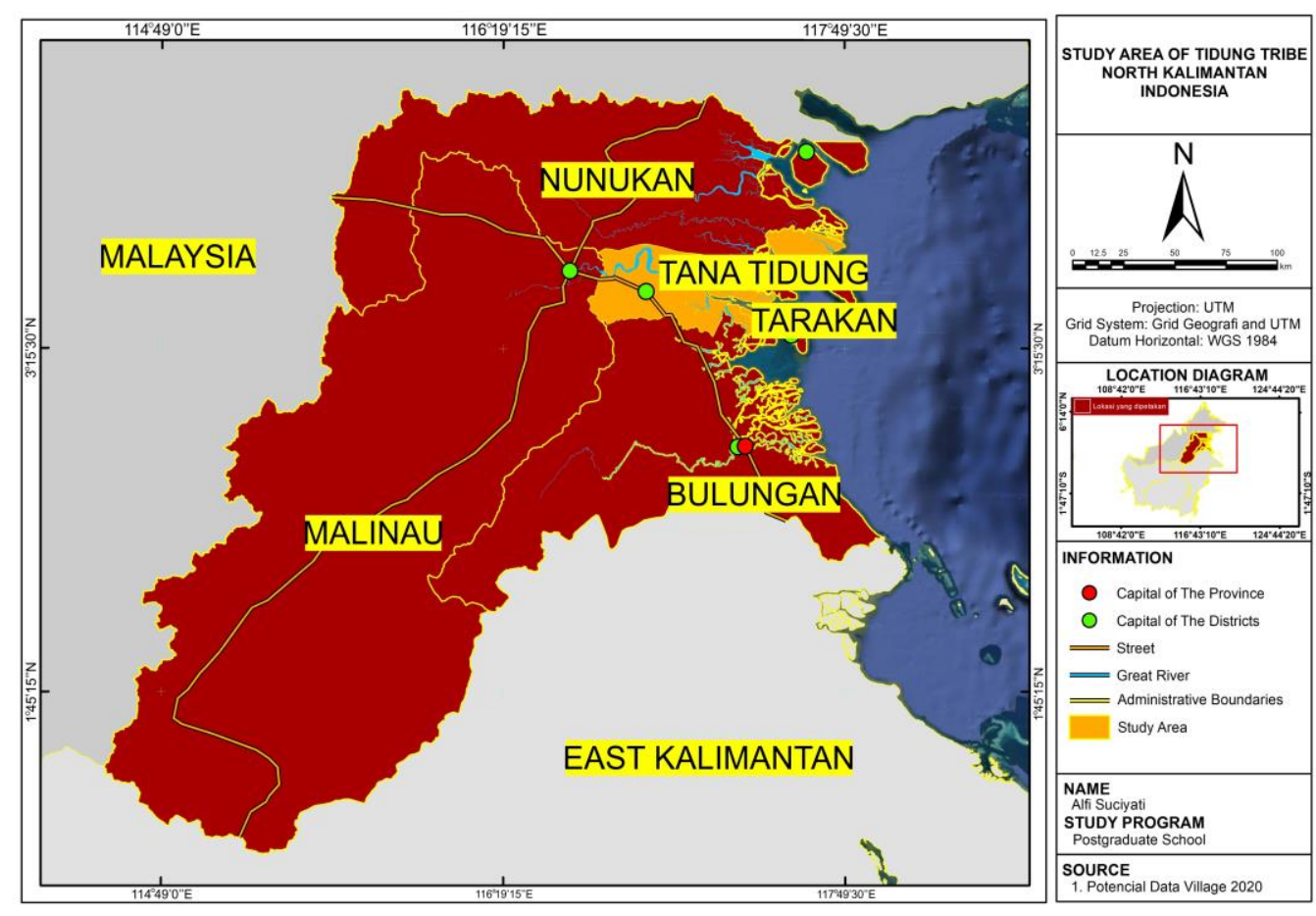

Figure 1. Location of Tana Tidung District, North Kalimantan, Indonesia 
Table 1. AI categorization

\begin{tabular}{ll}
\hline Availability & Index value \\
\hline Very many & 4.0 \\
Many & 3.0 \\
Average & 2.0 \\
Rare / endangered & 1.0 \\
& \\
Localization of usage & Index value \\
Everywhere & $=$ \\
Limited & -0.5 \\
Very limited & -1.0 \\
\hline
\end{tabular}

Table 2. FUI categorization

\begin{tabular}{ll}
\hline Usage frequency & Index value \\
\hline > once / week & 5.0 \\
Once/ week & 4.0 \\
Once/ month & 3.0 \\
> once/year < once/ month & 2.0 \\
Once/ year & 1.0 \\
Have never been used over the last 30 years & 0.5 \\
\hline
\end{tabular}

Table 3. PUI categorization

\begin{tabular}{ll}
\hline Usage frequency & Index value \\
\hline Bark & 1.0 \\
Root or rootstock & 1.5 \\
Root, young part & 1.0 \\
Tuber & 1.5 \\
Trunk & 1.0 \\
Leaf & 1.5 \\
Leaf Stalk & 1.0 \\
Young leaf & 1.0 \\
Leaf with a little part of trunk & 2.0 \\
Sprout & 1.25 \\
Sprout, young part & 0.75 \\
Bud & 0.75 \\
Flower & 0.75 \\
Receptacle & 0.75 \\
Fruit & 1.5 \\
Seed & 1.0 \\
All parts & 3.0 \\
All parts of young plants & 2.0 \\
\hline
\end{tabular}

\section{Data analysis}

The data obtained were analyzed qualitatively using tabulations. The species data and plant parts used by the Tidung tribe are presented in the table including the scientific name of the species, local names, and functions. The plant part data used were analyzed descriptively using percentages. AI, FUI and PUI data were obtained based on the results of interviews and were analyzed descriptively using tabulations.

\section{RESULTS AND DISCUSSION}

\section{Plant species used by Tidung Tribe}

The Tidung Tribe used as many as 60 plant species for food consumption (ngakan), shelter/construction (baloy), herbal medicine (sihat), traditional ceremonies (adat), and clothing (memana) (Table 4).

Most of the plants (33 species) have more than one function in the life of Tidung Tribe. The largest usage of those plants is for food (ngakan), 28 species, and traditional medicine (sihat), 24 species. The data show that Tidung Tribe still implements traditional herbal medication. Meanwhile, there are 23 species of plants for traditional ceremonies (adat), 21 species of plants for construction (baloy), and 5 species of plants for clothing (memana). A shift in the usage of plants for clothing has been happening for quite some time. Tidung Tribe currently uses ready-made materials for clothing. In general, plants used are limited to producing clothing or woven as raw materials for making traditional caps. The number of species and the illustration of plant usage distribution in the life of Tidung Tribe are presented in Figure 2.

\section{Food and medicine}

Tidung Tribe has variations in food processing both in terms of selecting basic ingredients, seasoning, spices, and condiments. The basic spices used in most Tidung Tribe dishes are shallots and garlic. Ginger, turmeric, and limes are often used to reduce fishy taste, especially in seafood dishes. Alpinia galanga, Syzygium polyanthum, Coriandrum sativum, and Kaempferia galanga are also often added to various types of dishes for flavor enhancement. Plant usage as food and traditional medication is essential for society's life. Investigation of knowledge about food and medicinal plants in a particular community and area is an important part of ethnobotany research (Haselmair 2014). People always take advantage of biodiversity especially plants as important food ingredients. Pierroni et al. (2016) state that biodiversity and food diversity are naturally connected. Thus, each food in different ethnic groups and areas has its own characteristics (Kuhnlein 2014; Kalle and Sõukand 2015).

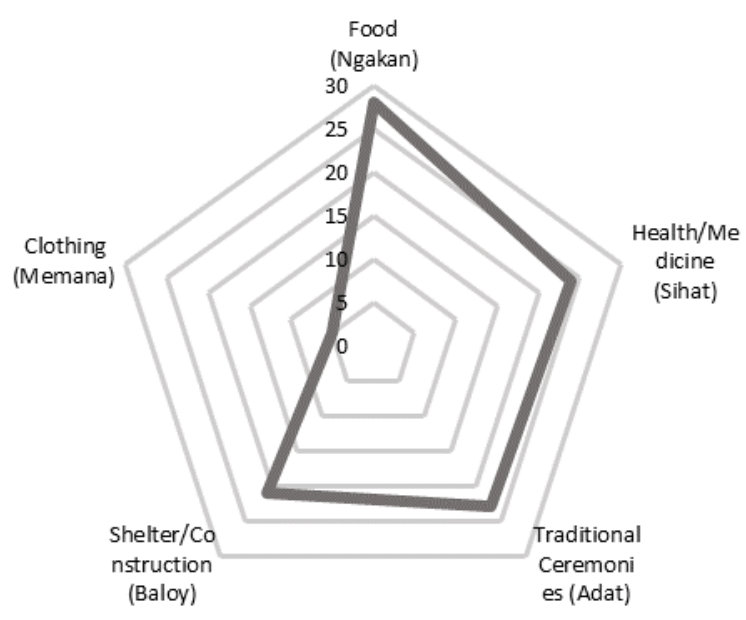

Figure 2. Plant usage distribution by Tidung Tribe 
Table 4. Plant species used by Tidung Tribe

\begin{tabular}{|c|c|c|c|}
\hline Species & Local name & Function & $\begin{array}{l}\text { Usage }\left(\mathrm{Ng}^{1}, \mathrm{Si}^{2}, \mathrm{Ba}^{3}, \mathrm{Ad}^{4}, \mathrm{Me}^{5}\right) \text { and } \\
\text { part being used }\end{array}$ \\
\hline Allium сера $\mathrm{L}$. & Bawang Lia & Herbs for food (seasoning), diabetes medication & Tuber $(\mathrm{Ng}, \mathrm{Si})$ \\
\hline Allium sativum $\mathrm{L}$. & Bawang Pulak & Food seasoning, warts medication & Tuber $(\mathrm{Ng}, \mathrm{Si})$ \\
\hline Alpinia galanga $(\mathrm{L}$.$) Willd.$ & Laus & Spice for food, asthma medication & Rhizome (Ng, Si) \\
\hline Areca catechu $L$. & Pinang, Gerat & Skin fungi medication, offering, building material & Fruit ( $\mathrm{Si}, \mathrm{Ad})$, Trunk (Ba) \\
\hline Artocarpus altilis (Parkinson ex F.A.Zorn) Fosberg & Baka, Sukun & Food, medication for stomach ache & Fruit $(\mathrm{Ng})$, Rind Trunk $(\mathrm{Si})$ \\
\hline Bambusa vulgaris var. striata (Lodd. ex Lindl.) Gamble & Buluh Silaw & Construction material/furniture, offering container & Trunk $(\mathrm{Ba}, \mathrm{Ad})$ \\
\hline Blumea balsamifera (L.) DC. & Sembung & Mosquito larvae eradication, postpartum care & Rind and all parts $(\mathrm{Si})$ \\
\hline Boehmeria nivea (L.) Gaudich. & Rami & Fabric/ Sack & Trunk (Me) \\
\hline Bougainvillea spectabilis Willd. & Busak Keratos & Offering, wedding decoration & Flower (Ad) \\
\hline Calamus rotang $\mathrm{L}$. & Rotan & Binding tool, furniture material, offering container & Trunk and root $(\mathrm{Ba}, \mathrm{Ad})$ \\
\hline Cananga odorata (Lam.) Hook.f. \& Thomson & Kenanga & Drink, offering & Flower $(\mathrm{Ng}, \mathrm{Si}, \mathrm{Ad})$ \\
\hline Capsicum anпиит $\mathrm{L}$. & Sabi, Sesula & Food seasoning, food ingredient & Fruit $(\mathrm{Ng})$ \\
\hline Citrus hystrix DC. & Limaw & Herbs for food, cure acne & Leaf, fruit $(\mathrm{Ng})$, Fruit $(\mathrm{Si})$ \\
\hline Clerodendrum calamitosum $\mathrm{L}$. & Kacibling & Dysentery medication, snake venom medication & Fruit, trunk, root $(\mathrm{Si})$ \\
\hline Cocos nucifera $\mathrm{L}$. & Piasaw & Ingredient for drink, construction, cure poisoning, and offerings & Fruit $(\mathrm{Ng}, \mathrm{Si}, \mathrm{Ad})$, Trunk (Ba) \\
\hline Coffea arabica $\mathrm{L}$. & Kupi & $\begin{array}{l}\text { Drinks, medication of shortness of breath (leaves part), traditional } \\
\text { ceremonies materials }\end{array}$ & $1 \mathrm{Seed}(\mathrm{Ng}, \mathrm{Si}, \mathrm{Ad})$ and leaf $(\mathrm{Si})$ \\
\hline Coriandrum sativum $\mathrm{L}$. & Ketumbor & Spices, stomach ache medication & Fruit $(\mathrm{Ng}, \mathrm{Si})$ \\
\hline Davallia sp. & Pakis Hias & Wedding decoration & Leaf $(\mathrm{Ad})$ \\
\hline Diplazium esculentum (Retz.) Sw. & Pakis Sayur & Vegetable & Young sprout $(\mathrm{Ng})$ \\
\hline Dipterocarpus sp. & Upun Keruing & Construction material/furniture, offering container & Trunk $(\mathrm{Ba}, \mathrm{Ad})$ \\
\hline Dryobalanops aromatica C.F.Gaertn. & Upun Kapur & Construction material/furniture, offering container & Trunk $(\mathrm{Ba}, \mathrm{Ad})$ \\
\hline Durio kutejensis Becc. & Durian Lia, Duyan Lia & Food ingredient, construction material, fever medication & Fruit $(\mathrm{Ng})$, Wood $(\mathrm{Ba})$, Root $(\mathrm{Si})$ \\
\hline Dyera costulata (Miq.) Hook.f. & Jelutung & Building raw material, Furniture & Trunk $(\mathrm{Ba})$ \\
\hline Eusideroxylon zwageri Teijsm. \& Binn. & Ulin & Building raw material & Trunk $(\mathrm{Ba})$ \\
\hline Gigantochloa apus Kurz & Buluh Betung & Construction material/furniture, offering container, caping frame & Trunk (Ba, Ad) \\
\hline Gigantochloa levis (Blanco) Merr. & Buluh Suluk & Construction material, offering container & Trunk (Ba, Ad) \\
\hline Helminthostachys zeylanica (L.) Hook. & Tunjuk langit & Inflammatory medication & $\operatorname{Root}(\mathrm{Si})$ \\
\hline Jasminum sambac (L.) Aiton & Busak Melati & Medicine, bee stings, offering in traditional ceremony & Flower $(\mathrm{Si}, \mathrm{Ad})$ \\
\hline Kaempferia galanga $\mathrm{L}$. & Kusur, Kuсur & Herbs, repel mosquitos, kill mosquito larvae & Rhizome (Ng, Si) \\
\hline Magnolia Champaca (L.) Baill. ex Pierre & Busak Cempaka & Traditional ceremony & Flower (Ad) \\
\hline Manihot esculenta Crantz. & Sabai & Staple food & Tuber $(\mathrm{Ng})$ \\
\hline Metroxylon sagu Rottb. & Sagu, Rumbia & Food ingredients, medication of flatulence & Trunk $(\mathrm{Ng}, \mathrm{Si})$ \\
\hline Michelia alba D.C. & Busak Susul Kantil & Offering & Flower (Ad) \\
\hline Musa $\times$ paradisiaca $\mathrm{L}$. & Punti Sanggar & Food ingredient, offering & Fruit $(\mathrm{Ng}, \mathrm{Ad})$ \\
\hline Musa textilis Née & Punti Ijou & Food, offering, fabric & Fruit $(\mathrm{Ng}, \mathrm{Ad})$, Trunk $(\mathrm{Me})$ \\
\hline
\end{tabular}


Nicotiana tabacum L.

Nypa fruticans Wurmb

Oryza sativa $\mathrm{L}$.

Oryza sativa var. glutinosa Blanco

Pandanus amaryllifolius Roxb.

Pandanus tectorius Parkinson ex Du Roi

Piper betle L.

Piper crocatum Ruiz \& Pav.

Piper nigrum L.

Rhodomyrtus tomentosa (Aiton) Hassk.

Rosa sp.

Shorea almon Foxw.

Shorea balangeran (Korth.) Burck

Shorea coriacea Burck

Shorea fallax Meijer

Shorea johorensis Foxw

Shorea laevis Ridl.

Solanum lycopersicum L.

Swietenia macrophylla

Syzygium polyanthum (Wight) Walp.

Tectona grandis L.f.

Uncaria gambir (Hunter) Roxb.

Vatica oblongifolia Hook.f

Zingiber montanum (J.Koenig) Link ex A.Dietr.

Zingiber officinale Roscoe.

Note: ${ }^{1}$ Ngakan (food), ${ }^{2}$ Sihat (herbal medicine), ${ }^{3}$ Baloy (shelter/construction), ${ }^{4}$ Adat (traditional ceremonies), ${ }^{5}$ Memana (clothing)
Offering

Food ingredient (nira), traditional cap raw material

Food ingredient, anti-acne powder, offering

Food ingredient, offering

Herbs, medication for dizziness

Ketan

Material for wall and hut, material for caping

Pandan Besar, Pandan

Tikar

Buyu

Sahang

Perijok, Pelijok

Busak Mawar

Gout medication

Herbs

Meranti Buaya Bukit Building raw material, Furniture

Balangeran, Kahoi, $\quad$ Building raw material, Furniture

Meranti Merah

Meranti Jurai, Samar Benua Building raw material, Furniture

Engkabang Layar, Kontoi Building raw material, Furniture

Merkuyung Building raw material, Furniture

Bengkirai

Tomat

Mahoni

Building raw material, Furniture

Food

Salam

Furniture materials, a dye for clothes

Herbs for food

Gambir

Construction material/furniture, offering container

Wound medication, offering

Building raw material, Furniture

Stamina improvement, kitchen spices

Banglai

Spices, warm bodies, cure fever
Leaf (Ad)

Fruit $(\mathrm{Ng})$, Leaf (Me)

Pulp (Ng, Si, Ad)

Pulp (Ng, Ad)

Leaf $(\mathrm{Ng}, \mathrm{Si})$

Leaf $(\mathrm{Ba}, \mathrm{Me})$

Leaf $(\mathrm{Si})$

Leaf $(\mathrm{Si})$

Fruit (Ng)

Fruit (Ng)

Flower (Si, Ad)

Trunk (Ba)

Trunk (Ba)

Trunk (Ba)

Trunk (Ba)

Trunk (Ba)

Trunk (Ba)

Fruit (Ng)

Trunk (Ba), Bark (Me)

Leaves $(\mathrm{Ng})$

Trunk (Ba, Ad)

Leaf $(\mathrm{Si})$, Flower $(\mathrm{Ad})$

Trunk (Ba)

Rhizome (Ng, Si)

Rhizome (Ng), Young Rhizome (Si) 
Different plant parts are used as raw materials for preparation of herbal medicine. The parts can be leaves, roots, flowers, seeds, rhizomes, and tubers. Most of the plants used for food are also used for preparation of medicine. Plants for food and health are interconnected because, basically, healthy plants are traditionally consumed as staple foods, spices, and condiments (Awuchi and Godswill 2019). The Zingiberaceae family (e.g Zingiber officinale, Kaempferia galanga) is most often used, both in cooking and in medicinal properties in the Tidung Tribe. The study of antioxidant activity (Danciu et al. 2015) showed increased polyphenols amount and antioxidant activity in the Zingiberaceae family tested. Not only in the Tidung Tribe, during the Covid 19 pandemic, but Zingiber officinale as an immune-enhancing drink is also increasingly being used in Indonesian society.

The Tidung Tribe has various traditional medicines. Information on the species of plants for traditional medicine of the Tidung Tribe in this study can be the initial information for modern medicine based on indigenous knowledge. Each tribe has a certain knowledge of the use of medicinal plants from the forest. This knowledge is very useful for the development of traditional medicines and the herbal medicine industry. Research on the properties of various species of medicinal plants used by the Tidung Tribe can be interesting as a continuation of the results of this study. The documentation of all useful plants with ethnomedicinal potential is also helpful in conserving plant biodiversity (Kumar et al. 2018).

\section{Traditional ceremonies}

The Tidung Tribe also has various traditional ceremonies, one of which is Iraw Tengkayu. This ceremony presents offerings in the form of special food and objects from Tidung Tribe placed and brought to the sea using decorated boats. In Iraw Tengkayu ceremony, plants used as food ingredients are used as offerings in the form of daily diets such as Cocos nucifera, Metroxylon sagu, Musa acuminata $\times$ balbisiana, and Oryza sativa var. glutinosa. For decorations purposes, flowers of Jasminum sambac, Michelia alba, Cananga odorata, and Bougainvillea spectabilis are used. In general, plants for decoration have special distinctive colors such as yellow ( $C$. odorata) and purple (B. spectabilis). Meanwhile, plants for offering containers are quite complex. For example, in Iraw Tengkayu ceremony, society makes a boat as the container to place offerings. The plants for boat frames are usually woody plants such as Dipterocarpus sp. and Tectona grandis. In addition, there are also plants for boat masts such as Bambusa vulgaris var. striata, and Gigantochloa apus.

Iraw Tengkayu ceremony symbolizes gratitude by Tidung society to God for the blessing they get from the sea (Sofyan 2017). Traditional ceremonies such as Iraw Tengkayu are also found in other tribes in Indonesia. For example, Sedekah Laut ceremony for the community in Pekalongan, Central Java (Wahyudi 2012), and the Mappadensasi ceremony for the Manggal ethnic group, North Sulawesi (Alkausar 2011). The purpose of these traditional ceremonies is almost the same, namely as a form of gratitude and hope for safety and abundant marine products. The plant species used in traditional ceremonies are different, but there is the same species namely rice (Oryza sativa). The use of various species of plants at the Iraw Tengkayu and other traditional ceremonies is in accordance with the statement that plants for traditional ceremonies are divided into three parts: for offerings in the form of food, for decoration in the form of flowers, and for containers of offering (Suswita et al. 2013).

\section{Constructions}

Plants species used for construction by Tidung Tribe are quite a lot, at least 21 species. Plants for construction have important roles: as basic building materials, foundation, windows, building walls, and boat making. The characteristics of plants are having hard and durable w0lood (Ijaz et al. 2017). Trunk is the most used part of plants for construction and other things (Figure 3).

Dipterocarpaceae family is widely used as a house construction material. Most of the Tidung Tribe's houses in Tana Tidung District are wooden houses (Figure 4a). Eusideroxylon zwageri, which is very strong, has been used as the main wood house frame or wood pillar. However, the species is currently endangered and expensive, Tidung society uses other species for timber, such as Shorea laevis (bengkirai). Areca catechu, wich has softer wood, is also used by the Tidung Tribe as a construction material.

\section{Clothing}

The last usage is for clothing (memana), which is not limited only to apparel but also accessories. Only a small part of plants is used for this memana group and the plants are only used for craft of traditional caps. Tidung's traditional cap is made from woven nipah leaves (Nypa fruticans) and bamboo sticks (Gigantochloa apus) (Figure 4b). Several plant species were made into fabrics, such as Bohmeria nivea and Musa textilia.

The Tidung tribe has several types of traditional clothing, but in this study, it was not found that the clothes were directly made using the plants around them. In Indonesia, there are many tribes who make traditional clothes using materials from plants that grow in their area. A study conducted by Rahayu \& Sihotang (2013) reported 9 species of plants used as clothing by tribes in Indonesia, namely Antiaris toxicaria Lesch., Artocarpus elasticus Reinw. ex Blume, A. integer (Thunb.) Merr., Boehmeria nivea (L.) Gaudich, Broussonetia papyrifera (L.) L'Her. ex Vent., Ficus minahassae (Teijsm. \& de Vriesse) Miq., F. pungens Reinw. ex Blume, F. variegata Reinw. ex Blume, and Streblus elongatus (Miq.) Corner. Apart from using plant materials for making clothes, the tribes in Indonesia also use various plants for dyeing fabrics. Rahayu et al (2020) reported 22 species used as fabric dyes and color binders in Traditional Pringgasela Woven Fabric, East Lombok, West Nusa Tenggara, Indonesia. These plants include Anacardium occidentale L., Areca catechu L., Curcuma longa L., Pterocarpus indicus Willd., and others.

The part of plants mostly used by Tidung Tribe is the trunk $(32 \%)$, followed by fruit/pulp $(21 \%)$. There are 9 species of plants in Dipterocarpaceae family used by 
Tidung Tribe. Meanwhile, fruit/pulp is widely used in daily life, such as foods, medicines, and traditional ceremonies.

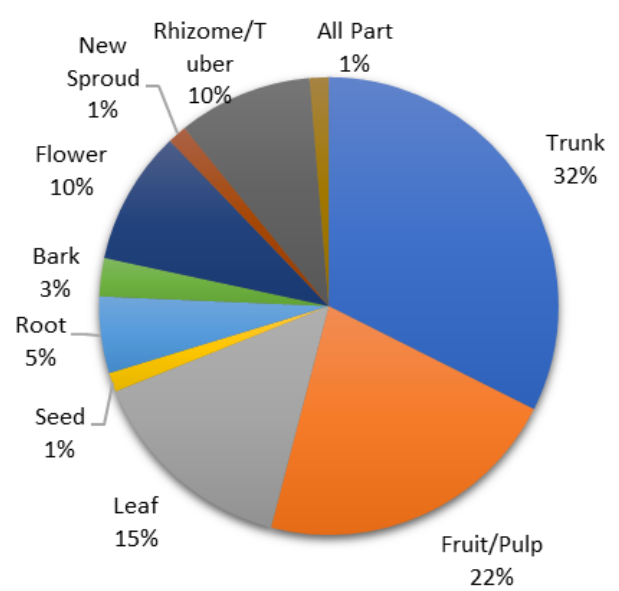

Figure 3. Percentage of plant parts used by Tidung Tribe

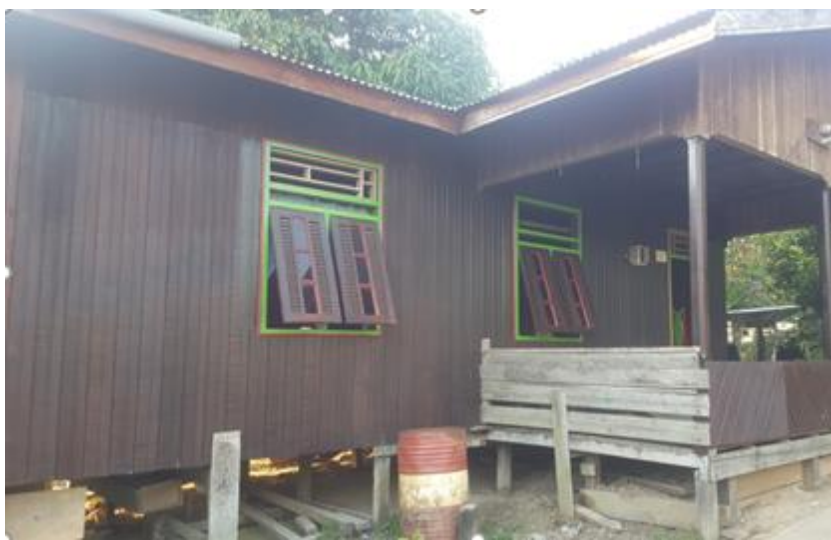

A

\section{AI, FUI, and PUI}

AI, FUI, and PUI assessment of each plant species are described in Table 5. There are 32 plant families. The most widely used families by Tidung Tribe are Dipterocarpaceae (9 species), followed by Poaceae (5 species), Zingiberaceae (4 species), Piperaceae (3 species), Solanaceae (3 species) and other families. Figure 5 shows five families that are mostly used. Several families such as Arecaceae, Pandanaceae, Solanaceae, Zingiberaceae, and Poaceae groups had the highest index values for AI and FUI. This is inversely proportional to Dipterocarpaceae family. Index value of AI and FUI of this family are low. The number of plants with high AI and FUI values indicates that these species in the Tana Tidung District area are quite abundant and often used to fulfill their daily lives. The highest PUI of plant is 3 . There is only one plant with the highest PUI value which is Cocos nucifera $\mathrm{L}$. All parts of this plant are used by society. This PUI value illustrates that more species of plants are used only in certain parts.

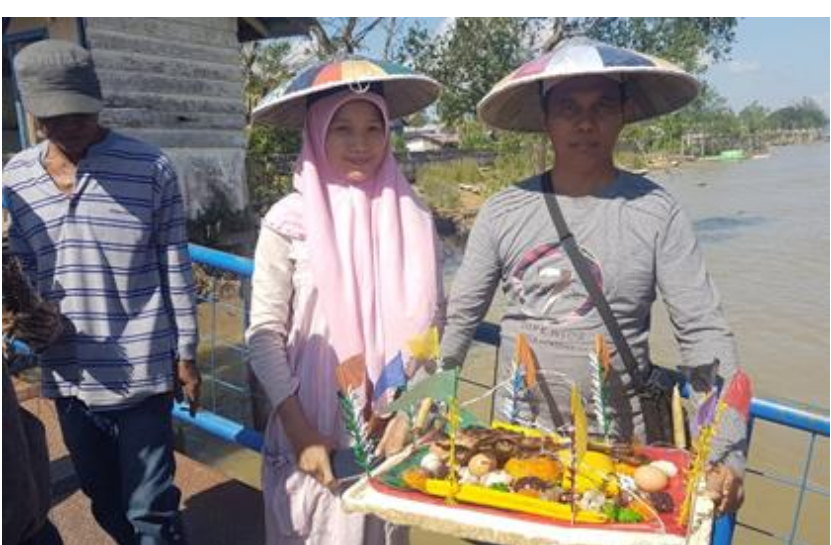

B

Figure 4. A. One of wooden houses of Tidung tribe with walls made of Shorea laevis. B. A Tidung Tribe wears a traditional cap and brings offerings for traditional ceremonies

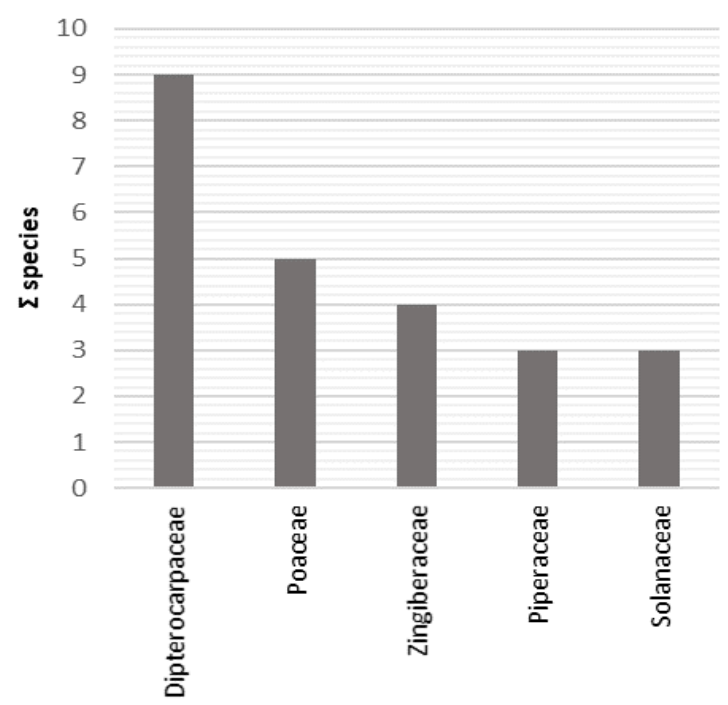

Figure 5. Five families (out of 32 families) that Tidung Tribe mostly uses

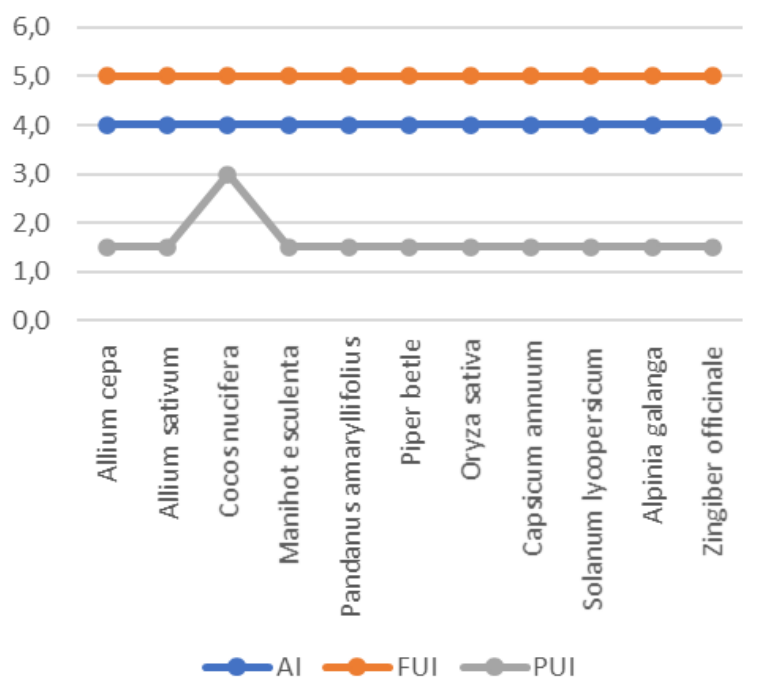

Figure 6. Eleven species with the highest AI and FUI values, completed with PUI values 
Table 5. Value Index of AI, FUI, and PUI

\begin{tabular}{|c|c|c|c|c|}
\hline Species & Family & AI & FUI & PUI \\
\hline Allium cepa $\mathrm{L}$. & Amaryllidaceae & 4,0 & 5,0 & 1,5 \\
\hline Allium sativum $\mathrm{L}$. & & 4,0 & 5,0 & 1,5 \\
\hline Cananga odorata (Lam.) Hook.f. \& Thomson & Annonaceae & 3,0 & 3,0 & 0,75 \\
\hline Coriandrum sativum $\mathrm{L}$. & Apiaceae & 3,0 & 5,0 & 1,5 \\
\hline Dyera costulata (Miq.) Hook.f. & Apocynaceae & 0,5 & 1,0 & 1,0 \\
\hline Areca catechu $L$. & Arecaceae & 4,0 & 4,0 & 1,5 \\
\hline Calamus rotang $\mathrm{L}$. & & 1,5 & 2,0 & 1,0 \\
\hline Cocos nucifera $\mathrm{L}$. & & 4,0 & 5,0 & 3,0 \\
\hline Metroxylon sagu Rottb. & & 1,5 & 3,0 & 1,0 \\
\hline Nypa fruticans Wurmb & & 3,0 & 4,0 & 1,5 \\
\hline Blumea balsamifera (L.) DC. & Asteraceae & 3,5 & 2,0 & 3,0 \\
\hline Diplazium esculentum (Retz.) Sw. & Athyriaceae & 3,0 & 4,0 & 0,75 \\
\hline Davallia sp. & Davalliaceae & 3,0 & 1,0 & 1,5 \\
\hline Dipterocarpus sp. & Dipterocarpaceae & 0,5 & 1,0 & 1,0 \\
\hline Dryobalanops aromatica C.F.Gaertn. & & 1,0 & 1,0 & 1,0 \\
\hline Shorea almon Foxw. & & 0,5 & 1,0 & 1,0 \\
\hline Shorea balangeran (Korth.) Burck & & 0,5 & 1,0 & 1,0 \\
\hline Shorea coriacea Burck & & 0,5 & 0,5 & 1,0 \\
\hline Shorea fallax Meijer & & 0,5 & 0,5 & 1,0 \\
\hline Shorea johorensis Foxw & & 0,5 & 1,0 & 1,0 \\
\hline Shorea laevis Ridl. & & 1,0 & 1,0 & 1,0 \\
\hline Vatica oblongifolia Hook.f & & 0,5 & 1,0 & 1,0 \\
\hline Manihot esculenta Crantz. & Euphorbiaceae & 4,0 & 5,0 & 1,5 \\
\hline Clerodendrum calamitosum $\mathrm{L}$. & Lamiaceae & 3,0 & 1,0 & 1,5 \\
\hline Eusideroxylon zwageri Teijsm. \& Binn. & Lauraceae & 0,5 & 1,0 & 1,0 \\
\hline Magnolia Champaca (L.) Baill. ex Pierre & Magnoliaceae & 4,0 & 3,0 & 0,75 \\
\hline Michelia alba D.C. & & 3,0 & 1,0 & 0,75 \\
\hline Durio kutejensis Becc. & Malvaceae & 1,5 & 2,0 & 1,5 \\
\hline Swietenia macrophylla & Meliaceae & 1,0 & 2,0 & 1,0 \\
\hline Artocarpus altilis (Parkinson ex F.A.Zorn) Fosberg & Moraceae & 2,0 & 3,0 & 1,5 \\
\hline Musa $\times$ paradisiaca $\mathrm{L}$. & Musaceae & 3,0 & 2,0 & 1,5 \\
\hline Musa textilis Née & & 2,0 & 2,0 & 1,5 \\
\hline Rhodomyrtus tomentosa (Aiton) Hassk. & Myrtaceae & 1,5 & 2,0 & 1,5 \\
\hline Syzygium polyanthum (Wight) Walp. & & 3,0 & 5,0 & 1,5 \\
\hline Bougainvillea spectabilis Willd. & Nyctaginaceae & 3,0 & 1,0 & 0,75 \\
\hline Jasminum sambac (L.) Aiton & Oleaceae & 4,0 & 3,0 & 0,75 \\
\hline Helminthostachys zeylanica (L.) Hook. & Ophioglossaceae & 2,0 & 2,0 & 1,5 \\
\hline Pandanus amaryllifolius Roxb. & Pandanaceae & 4,0 & 5,0 & 1,5 \\
\hline Pandanus tectorius Parkinson ex Du Roi & & 4,0 & 4,0 & 1,5 \\
\hline Piper betle L. & Piperaceae & 4,0 & 5,0 & 1,5 \\
\hline Piper crocatum Ruiz \& Pav. & & 3,0 & 5,0 & 1,5 \\
\hline Piper nigrum $\mathrm{L}$ & & 1,5 & 2,0 & 1,5 \\
\hline Bambusa vulgaris var. striata (Lodd. ex Lindl.) Gamble & Poaceae & 3,0 & 2,0 & 1,0 \\
\hline Gigantochloa apus Kurz & & 3,0 & 2,0 & 1,0 \\
\hline Gigantochloa levis (Blanco) Merr. & & 4,0 & 3,0 & 1,0 \\
\hline Oryza sativa $\mathrm{L}$ & & 4,0 & 5,0 & 1,5 \\
\hline Oryza sativa var. glutinosa Blanco & & 4,0 & 4,0 & 1,5 \\
\hline Rosa sp. & Rosaceae & 4,0 & 3,0 & 0,75 \\
\hline Coffea arabica $\mathrm{L}$ & Rubiaceae & 3,0 & 5,0 & 1,0 \\
\hline Uncaria gambir (Hunter) Roxb. & & 3,0 & 2,0 & 1,5 \\
\hline Citrus hystrix DC. & Rutaceae & 3,0 & 5,0 & 1,5 \\
\hline Capsicum annuum $\mathrm{L}$. & Solanaceae & 4,0 & 5,0 & 1,5 \\
\hline Nicotiana tabacum L. & & 2,0 & 2,0 & 1,5 \\
\hline Solanum lycopersicum $\mathrm{L}$. & & 4,0 & 5,0 & 1,5 \\
\hline Boehmeria nivea (L.) Gaudich. & Urticaceae & 2,0 & 3,0 & 1,0 \\
\hline Tectona grandis L.f. & Verbenaceae & 2,0 & 1,0 & 1,0 \\
\hline Alpinia galanga (L.) Willd. & Zingiberaceae & 4,0 & 5,0 & 1,5 \\
\hline Kaempferia galanga $\mathrm{L}$. & & 3,0 & 5,0 & 1,5 \\
\hline Zingiber montanum (J.Koenig) Link ex A.Dietr. & & 3,0 & 5,0 & 1,5 \\
\hline Zingiber officinale Roscoe. & & 4,0 & 5,0 & 1,5 \\
\hline
\end{tabular}


Arecaceae, Pandanaceae, Solanaceae, Zingiberaceae, and Poaceae groups have the highest index value for AI and FUI because these families are the staple food of the community which are generally used in daily activities. Figure 6 shows plot graphic of 11 species with the highest AI and FUI values, completed with PUI values. Families that have low values of AI and FUI are those plants rarely found in nature. This study indicates species in the Dipterocarpaceae family are widely used by the Tidung tribe, especially for building construction, but these species are increasingly rare. For example, Shorea johorensis is categorized as Critically Endangered plants (IUCN 2.3) (Ashton, 1998). Other species that have low value of AI are Eusideroxylon zwageri (ironwood) and Dyera costulata (jelutong wood). Eusideroxylon zwageri is categorized Vulnerable Plant (VU) (IUCN 2.3) (Asian Regional Workshop, 1998). It has long been known as a high-quality wood, one of the hardest timber species in Southeast Asia, but its growth rate is very slow and becomes endangered in some parts of Southeast Asia (Komara et al. 2016; Gibson and Rebicca 2016). Based on the AI index that has been compiled in this study, we also need to be aware of species whose existence in nature is increasingly rare. Utilization of biological biodiversity is deep-rooted in every tribe in Indonesian society (von Rintelen 2017), but the conservation of this biodiversity is often very lacking.

Ngakan (eat), baloy (construction), sihat (health/ medication), adat (worship and traditional ceremonies), and memana (clothing) in Tidung Tribe represents five aspects that are necessary for human life. Tidung Tribe uses all species of plants in this research to fulfill their basic needs. Various plant species have long played an important role in humanity (Faruque et al. 2018). The various species used by the Tidung Tribe are also local potentials of the Tana Tidung area, constituting the region's wealth or resources (Suciyati and Yulinda, 2019). North Kalimantan has a variety of natural resources both at sea and on land (Suciyati et al. 2019). Ethnobotanical knowledge has a vital role in managing natural resources (Navia et al. 2020).

\section{ACKNOWLEDGEMENTS}

We would like to thank the Directorate of Research and Community Service, Ministry of Research and Technology, Republic of Indonesia which funded this research with contract number T/2.1.20/UN34.21/PT.01.03/2020. Many thanks to Yogyakarta State University for the support of this study. Lastly, we would like to thank the anonymous reviewers and journal editors for their valuable comments, which greatly improved our manuscript.

\section{REFERENCES}

Alkausar M. 2011. The threat of the destruction of the Mappadensation ritual in the Mandar ethnic community of Bungkutoko Village, Southeast Sulawesi. [Thesis]. Universitas Udayana, Denpasar. [Indonesian]
Ananta A, Arifin EN, Hasbullah MS, Handayani NB, Pramono A. 2014. A New Classification of Indonesia's Ethnic Groups (Based on the 2010 Population Census). ISEAS Working Paper. Institute of Southeast Asian Studies, Singapore.

Ashton P. 1998. Shorea johorensis. The IUCN Red List of Threatened Species 1998: e.T33119A9758343. 10.2305/IUCN.UK.1998.RLTS.T33119A9758343.en.

Asian Regional Workshop (Conservation \& Sustainable Management of Trees, Viet Nam, August 1996). 1998. Eusideroxylon zwageri. The IUCN Red List of Threatened Species 1998: e.T31316A9624725. DOI: 10.2305/IUCN.UK.1998.RLTS.T31316A9624725.en.

Awuchi, Godswill C. 2019. Medicinal plants: the medical, food, and nutritional biochemistry and uses. Intl J Adv Acad Res 5:220-241.

BPS (Statistics Indonesia). 2012. Population of Indonesia. Result of Indonesia Population Census 2010. BPS, Jakarta. https://www.bps.go.id/publication/download. [Indonesian]

Cocks M. 2010. What is Biocultural Diversity? A Theoretical Review. In: Bates D, Tucker J (eds). Human Ecology. Springer, Boston, MA. DOI: 10.1007/978-1-4419-5701-6 5

Danciu C, Vlaia L, Fetea F, Hancianu M, Coricovac DE, Ciurlea SA, Soica CM, Marincu I, Vlaia V, Dehelean CA, Trandafirescu C. 2015. Evaluation of phenolic profile, antioxidant and anticancer potential of two main representants of Zingiberaceae family against B164A5 murine melanoma cells. Biol Res 48: 1-9. DOI:10.1186/0717-628748-1

Davidson-Hunt IJ, Turner KL, Mead ATP, Cabrera-Lopez J, Bolton R, Idrobo CJ, Miretski I, Morrison A, Robson JP. 2012. Biocultural design: a new conceptual framework for sustainable development in rural indigenous and local communities. Sapiens 5: 33-45. http://journals.openedition.org/sapiens/1382.

Faruque MO, Uddin SB, Barlow JW, Hu S, Dong S, Cai Q, Li X, Hu X. 2018. Quantitative ethnobotany of medicinal plants used by indigenous communities in the Bandarban District of Bangladesh. Front Pharmacol 9: 1-12. DOI: 10.3389/fphar.2018.00040.

Gibson E, Rebicca E. 2016. Induction of shoot buds multiplication of Eusideroxylon zwageri Tesym. \& Binned (Borneo ironwood) by using nodal explants. Adv Plants Agric Res 5: 551-555. DOI: 10.15406/apar.2016.05.0018.

Haselmair R, Pirker H, Kuhn E, Vogl CV. 2014. Personal networks: a tool for gaining insight into the transmission of knowledge about food and medicinal plants among Tyrolean (Austrian) migrants in Australia, Brazil and Peru. J Ethnobiol Ethnomed 10: 1-24. DOI: 10.1186/17464269-10-1.

Hidayati S, Franco FM, Bussmann RW. 2015. Ready for phase 5 - current status of ethnobiology in Southeast Asia. J Ethnobiol Ethnomed 11: 1-8. DOI: 10.1186/s13002-015-0005-7.

Hunn E. 2007. Ethnobiology in four phases. J Ethnobiol. 27: 1-10. DOI: 10.2993/0278-0771(2007)27[1: EIFP]2.0.CO;2.

Ijaz F, Iqbal Z, Rahman IU, Ali N, Afzal M. 2017. People-plants interaction and its uses: a science of four words "Ethnobotany". Altern Integr Med 6: 1-2. DOI: 10.4172/2327-5162.1000235

Kalle R, Sõukand R. 2015. Emic conceptualization of a 'wild edible plant' in Estonia in the second half of the 20th century. Trames 19: 15-34. DOI: 10.3176/tr.2015.1.02.

Komara LL, Choesin DN, Syamsudin TS. 2016. Plant diversity after 16 years post coal mining in East Kalimantan, Indonesia. Biodiversitas 17: 531-538. DOI: 10.13057/biodiv/d170220.

Kuhnlein HV. 2014. How ethnobiology can contribute to food security. J Ethnobiol 34:12-27. DOI:10.2993/0278-0771-34.1.12.

Kumar S, Das G, Shin HS, Kumar P, Patra JK. 2018. Diversity of plant species in The Steel City of Odisha, India: ethnobotany and implications for conservation of urban bio-resources. Brazilian Arch Biol Technol 61: 1-19. DOI:10.190/1678-4324-2018160650.

Lesmana H, Alfianur A, Utami PA, Retnowati Y, Darni D. 2018. Traditional medicine in Tidung community, Tarakan City: qualitative study of local wisdom in health. Medisains 16: 31-41. DOI: 10.30595/medisains.v16i1.2161.

Listiani L, Abrori FM. 2019. Ethnobotanical study on Tidung Tribe in using plants for medicine, spice, and ceremony. IPTEK J Technol Sci 29: 18-24. DOI:10.12962/j20882033.v29i1.3057.

Maffi L. 2007. Biocultural diversity and sustainability. In: Pretty J, Ball AS, Benton T (eds.) The SAGE Handbook of Environment and Society. SAGE Publications Ltd., New York. 
Navia ZI, Audira D, Afifah N, Turnip K, Nuraini, Suwardi AB, 2020 Ethnobotanical investigation of spice and condiment plants used by the Taming tribe in Aceh, Indonesia. Biodiversitas 21: 4467-4473.

Pieroni A, Pawera L, Shah GM. 2016. Gastronomic ethnobiology. In: U.P. Albuquerque UP, Alves R (eds) Introduction to Ethnobiology. Springer International Publishing, Switzerland.

Pieroni A. 2001. Evaluation of cultural significance of wild food botanicals traditionally consumed in Northwestern Tuscany, Italy. J Ethnobiol 2: 89-104.

Rahayu M, Sihotang BL. 2013. Bark fiber clothing materials: its diversity and prospect in Indonesia. Berita Biologi 12: 269-275. DOI 10.14203/beritabiologi.v12i3.620.

Rahayu M, Kuncari ES, Rustiami H, Susan D. 2020. Utilization of plants as dyes and natural color binder in traditional Pringgasela woven fabric, East Lombok, West Nusa Tenggara, Indonesia. Biodiversitas 21:641-636. DOI: 10.13057/biodiv/d210228.

Ramage MH, Burridge H, Busse-Wicher M, Fereday G, Reynolds T, Shah DU, Wu G, Yu L, Fleming P, Densley-Tingley D, Allwood J, Dupree P, Linden PF, Scherman O. 2017. The wood from the trees: The use of timber in construction. Renew Sustain Energ Rev 68:333-359. DOI: 10.1016/j.rser.2016.09.107.

Rotherham, ID. 2015. Bio-cultural heritage and biodiversity: emerging paradigms in conservation and planning. Biodivers Conserv 24: 34053429. DOI:10.1007/s10531-015-1006-5.

Simbiak M, Supriatna J, Walujo EB, Nisyawati. 2019. Current status of ethnobiological studies in Merauke, Papua, Indonesia: A perspective of biological-cultural diversity conservation. Biodiversitas 20: $3455-$ 3466. DOI: 10.13057/biodiv/d201201.

Sofyan A. 2017. Ecological intelligence based on local wisdom of Tidung Tribe Tarakan in Social Studies Learning. In: Abdullah AG, Hamidah I, Aisyah S, Permanasari A, Adriany V (eds). Proceeding of the 2nd Asian Education Symposium (AES). Indonesia University of Education, Lombok Mataram, 6-7 November 2017. [Indonesian]

Sterling EJ, Gómez A, Porzecanski AL. 2010. A systemic view of biodiversity and its conservation: processes, interrelationships, and human culture: presentation of a systemic view of biodiversity and its conservation that emphasizes complex interrelationships among subsystems and includes human culture. Bioessays 32: 1090-1098. DOI: 10.1002/bies.201000049.

Suciyati A, Yulinda R, Nursia. 2019. Increasing the economy of seaweed farmers through the Processed Seaweed Product Diversification Program (DIPORLA) in Pantai Amal Village, East Tarakan District, Tarakan City, North Kalimantan. ETHOS (Jurnal Penelit dan Pengabdian) 7: 129-136. DOI: 10.29313/ethos.v7i1.4244. [Indonesian]

Suciyati A, Yulinda R. 2019. Students' perception on seaweed resources at Amal Beach North Borneo. J Phys: Conf Ser 1254: 1-6. DOI:10.1088/1742-6596/1254/1/012021.

Suryadarma IGP. 2011. Rukmini Tatwa, a balinese script, on the diversity of plant use for human body fitness. Biota 15: 290-300.

Suryadarma IGP. 2019. Biodiversity and ecological phenomena in Pranatamongso calendar: basic knowledge and goal for optimizing of crop production in Javanese farmers. J Phys Conf Ser 1317:1-11. DOI: 10.1088/1742-6596/1317/1/012183.

Suswita D, Syamsuardi, Arbain A. 2013. Ethnobotany studies and the form of plant conservation efforts used in Kendurisko traditional ceremonies in several sub-districts in Kerinci Jambi Regency. J Biol 2: $67-80$.

Tana Tidung District Goverment. 2012. Demographics of Tana Tidung District. Tana Tidung District Government, Tana Tidung. [Indonesian]

Tana Tidung District Government. 2015. RPI2-JM Review Report for Tana Tidung District 2015. Tana Tidung District Government, Tana Tidung. [Indonesian]

von Rintelen K, Arida E, Häuser C. 2017. A review of biodiversity-related issues and challenges in megadiverse Indonesia and other Southeast Asian countries. Res Ideas Outcomes 3: e20860. DOI: 10.3897/rio.3.e20860.

Wahyudi, SS. 2011. 'Sedekah Laut' tradition for in the fhisherman community in Pekalongan, Central Java. J Coast Dev 14: 262-270. 